Life Science

http://journal.unnes.ac.id/sju/index.php/LifeSci

\title{
Pengaruh Paparan Rokok Elektrik terhadap kadar GPx dan Catalase pada darah Tikus
}

Mira Putri Agustin ${ }^{\bowtie 1)}$, Lisdiana ${ }^{2)}$

1),2) Jurusan Biologi, Fakultas Matematika dan Ilmu Pengetahuan Alam Universitas Negeri Semarang, Indonesia

\section{Info Artikel}

Diterima: 1 Maret 2021

Disetujui: 30 Maret 2021

Dipublikasikan: 15 April 2021

Keywords: Electric cigarettes, GPx, catalase

Rokok elektrik, GPx, katalase

\begin{abstract}
Electric cigarettes are cigarettes that are used with battery power, but do not burn tobacco like ordinary cigarette products. Electric cigarettes were initially said to be safe for health because nicotine solutions contained in ecigarettes only consist of a mixture of water, propylene glycol, flavor enhancing substances, the aroma of tobacco, and other compounds that do not contain tar, tobacco or other toxic substances common in tobacco cigarettes. Electric cigarettes contain free radical compounds that can cause oxidative stress. In conditions of oxidative stress, free radical compounds increase lipid peroxide. In normal enzyme activity, an increase in the concentration of substrate, namely the molecule hydrogen peroxide (H2O2) can increase enzyme activity. But when the active side of all enzymes binds to the substrate, the addition of the substrate cannot increase the speed of the next enzyme reaction, resulting in a decrease in enzyme activity. This study aimed to analyze the levels of GPx and catalase in rat blood exposed to electrocution cigarettes. The study was conducted on 30 male white rats of Wistar strain which were divided into 5 groups, namely $K$ - (negative control), $K+$ (positive control), $K P 1$ (treatment 1), KP2 (treatment 2) and KP3 (treatment 3). The $K+$ group is a positive control group with 3 cigarettes and KP1,KP2, KP3 electric cigarette treatment groups treated with e-cigarettes with a dose of nicotine $3 \mathrm{mg}, 6 \mathrm{mg}, 9 \mathrm{mg}$ for 30 days. To find out the difference in GPx and catalase levels, each group was analyzed by using one way annova and LSD for parametric test, while for non-parametric tests using the kruskal wallis test and Mann Whitney test. The results of the analysis showed that all between groups $K$-, $K$ $+, K P 1, K P 2$ and KP3 were significantly different, in the KP3 group had the level of $G p x(40.25 \pm 2.03 e)$ and catalase (2.46 \pm 9.50 e) which was the lowest due to exposure electric cigarette with the highest dose of nicotine which is $9 \mathrm{mg}$.
\end{abstract}

\begin{abstract}
Abstrak
Rokok elektrik adalah rokok yang digunakan dengan tenaga baterai, namun tidak membakar tembakau seperti produk rokok biasa. Rokok elektrik pada awalnya dikatakan aman bagi kesehatan karena larutan nikotin yang terdapat pada rokok elektrik hanya terdiri dari campuran air, propilen glikol, zat penambah rasa, aroma tembakau, serta senyawa-senyawa lain yang tidak mengandung tar, tembakau atau zat-zat toksik lain yang umum terdapat pada rokok tembakau. Rokok elektrik mengandung senyawa radikal bebas yang dapat menyebabkan stress oksidatif. Pada kondisi stress oksidatif, senyawa radikal bebas meningkatkan peroksida lipid. Dalam aktivitas enzim yang normal, peningkatan konsentrasi subtrat, yaitu molekul hidrogen peroksida $\left(\mathrm{H}_{2} \mathrm{O}_{2}\right)$ dapat meningkatkan aktivitas enzim. Namun pada saat sisi aktif semua enzim berikatan dengan substrat, penambahan substrat tidak dapat meningkatkan kecepatan reaksi enzim selanjutnya, sehingga terjadi penurunan aktivitas enzim. Penelitian ini bertujuan untuk menganalisis kadar GPx dan katalase pada darah tikus yang dipapar rokok elktrik. Penelitian dilakukan pada 30 ekor tikus putih jantan galur Wistar yang dibagi menjadi 5 kelompok, yaitu K(kontrol negatif), K+ (kontrol positif), KP1 (perlakuan 1), KP2 (perlakuan 2) dan KP3 (perlakukan 3). Kelompok K+ merupakan kelompok kontrol positif dengan perlakuan rokok elektrik 3 batang dan kelompok KP1, KP2, KP3 merupakan kelompok perlakukan dengan rokok elektrik dosis nikotin $3 \mathrm{mg}, 6 \mathrm{mg}$, $9 \mathrm{mg}$ selama 30 hari. Untuk mengetahui perbedaan kadar GPx dan katalase setiap kelompok dilakukan analalisis data menggunakan uji one way annova dan LSD untuk parametrik sedangkan untuk non parametrik menggunakan uji kruskal wallis dan uji mann whitney. Hasil analisis menunjukkan semua antar kelompok K-, K+, KP1, KP2 dan KP3 berbeda nyata, pada kelompok KP3 memiliki kadar Gpx $\left(40,25 \pm 2,03^{\mathrm{e}}\right)$ dan katalase $\left(2,46 \pm 9,50^{\mathrm{e}}\right)$ yang paling rendah akibat dipapar rokok elektrik dengan dosis nikotin paling tinggi yaitu $9 \mathrm{mg}$.
\end{abstract}

(C) 2021 Universitas Negeri Semarang

$\square$ Alamat korespondensi: p-ISSN 2252-6277

Gedung D6 Lt.1 J1 Raya Sekaran Gunugpati, Semarang e-ISSN 2528-5009 


\section{PENDAHULUAN}

Rokok adalah suatu bentuk bahan lain dari tembakau yang banyak digunakan oleh penduduk di dunia. Indonesia menjadi salah satu konsumen terbesar dalam konsumsi rokok yang dibuktikan dengan Indonesia menduduki peringkat ketiga sebagai negara perokok terbanyak setelah China dan India (WHO, 2013). Berdasarkan riset Atlas Tobbaco tahun 2016, Indonesia menduduki ranking tiga negara dengan jumlah perokok tertinggi di dunia. Jumlah perokok di Indonesia mencapai 90 juta jiwa. Indonesia menempati urutan tertinggi prevalensi merokok bagi laki-laki di ASEAN yakni sebesar 67,4 \%. Komnas Perlindungan Anak Indonesia (KPAI) Kota Jakarta menyebut jumlah perokok pemula meningkat hingga $45 \%$. KPAI juga berpendapat dengan keterjangkauan membeli rokok dengan cukai yang murah menjadikan salah satu penyebab banyak perokok pemula di usia dini yang hampir $80 \%$ nya mulai merokok ketika usianya belum mencapai 19 tahun. Hasil Riset Kesehatan Dasar (Riskesdas) pada tahun 2013 menyatakan bahwa perilaku merokok penduduk Indonesia di usia 15 tahun keatas masih belum terjadi penurunan, berdasarkan survei yang dilakukan pada tahun 2007 sebesar 34,2\% meningkat menjadi 36,3\% pada tahun 2013 (Hasna et al., 2017).

Merokok dapat menyebabkan beberapa gangguan terutama pada sistem pernapasan yaitu Penyakit Paru Obstruksi Kronis (PPOK). Penyakit Paru Obstruksi Kronis (PPOK) adalah penyakit peradangan paru yang berkembang dalam jangka waktu panjang. Penyakit ini menghalangi aliran udara dari paru-paru karena terhalang pembengkakan dan lendir atau dahak, sehingga penderitanya sulit bernapas. Kemudain di 12 negara Asia Pasifik menunjukkan estimasi prevalensi PPOK Indonesia sebesar 5,6\% (Christensen et al., 2016). Menurut Raherison \& Girodet (2009) prevalensi PPOK diperkirakan 7,6\%. Dampak lain yang ditimbulkan akibat kebiasaan merokok dapat menyebabkan perubahan struktur dan fungsi berbagai macam organ. Telah diketahui bahwa rokok mengandung berbagai macam bahan kimia yang terkandung di dalamnya. Apabila rokok tersebut dinyalakan, akan menghasilkan sekitar 4.800 jenis senyawa bahan kimia, di antaranya adalah nikotin, gas karbon monoksida, nitrogen oksida, hydrogen cyanide, tar, ammonia, akrolein, benzene, dan etanol. Beberapa kandungan rokok tersebut dapat memberikan dampak buruk terhadap kesehatan. Asap yang ditimbulkan dari pembakaran tersebut memiliki kadar oksidan bebas yang tinggi, setiap asap rokok yang terhirup mengandung 1015-1018 molekul oksidan. Radikal bebas dari asap rokok merupakan zat toksik bagi tubuh yang berpotensi merusak sel (Apreliantino, 2012).

Seiring berkembangnya teknologi, jenis rokok yang sering dikonsumsi oleh masyarakat yakni rokok konvensional dan rokok elektrik sebagai temuan terbaru yang beredar pada kalangan muda. Rokok elektrik merupakan inovasi untuk membantu mengurangi ketergantungan dan sebagai alat berhenti merokok dari rokok konvensional. Rokok elektrik atau Elestronic Nicotine Delivery System (ENDS) yaitu teknologi rokok terkini berupa alat yang dioperasikan dengan baterai yang dimana rokok sudah diolah dalam bentuk cairan dengan kerjanya yaitu merubah zat-zat kimia yang terkandung dalam cairan menjadi uap hasil pemanasan baterai dan megalirkannya ke tubuh perokok. Banyak masyarakat beranggapan bahwa ENDS lebih sehat bila dibandingkan dengan rokok konvesional yang berbahan tembakau 
(Rohmani et al., 2018). Hal ini disebabkan oleh bahan kimia yang terdapat pada ENDS lebih sedikit dibandingkan dengan rokok konvesional. Departemen kesehatan melaporkan ENDS mempunyai kandungan proeplin glikol, gliserol, air suling, perasa dan nikotin pelarut atau nikotin plus plester, yang akan berubah menjadi nitronisme bila terkena panas. Nitronisme merupakan salah satu penyebab kanker (Tooy et al., 2016).

Dalam menghadapi serangan radikal bebas, tubuh memiliki mekanisme perlindungan melalui sistem antioksidan tubuh. Secara umum antioksidan dibagi menjadi dua, yaitu antioksidan enzimatis yang berasal dari dalam tubuh (endogen), antara lain enzim superoksida dismutasi (SOD), katalase, glutation peroksidase (GPx), dan antioksidan non enzimatis yang berasal dari luar dalam tubuh (eksogen), antara lain Vitamin C, Vitamin E, betakaroten dan senyawa flavonoid yang diperoleh dari tumbuhan (Chevion et al., 2003). Antioksidan enzimatik (endogen) seperti Glutation peroksidase (GPx) adalah enzim yang berfungsi mengatabolisme hidrogen peroksida $\left(\mathrm{H}_{2} \mathrm{O}_{2}\right)$ (Ifanyanti, 2017).

Secara fisiologis radikal bebas yang berasal dari rokok yang masuk ke dalam saluran napas bronkus akan didetoksifikasi oleh sel makrofag, neutrofil, dan eosinofil. Namun, peningkatan jumlah eosinofil yang dapat menimbulkan reaksi inflamasi. Radikal bebas utama yang berperan terjadinya reaksi inflamasi adalah radikal superoxide dikarenakan memiliki waktu paruh yang lebih panjang sehingga jumlah sel target yang terkena menjadi lebih besar sehingga dapat menimbulkan kerusakan dan kematian sel yang lebih banyak (Gutowski \& Kowalczyk, 2013). Inflamasi yang terjadi pada saluran pernapasan akan membuat kerusakan sel-sel silia bronkus dan bronkiolus, yang secara fisiologis berfungsi sebagai pelindung paru melalui penyaringan berbagai partikel yang terhirup ke dalam saluran napas. Kerusakan sel-sel silia pada saluran napas akan mengakibatkan terjadinya hipersekresi mukus sehingga menyebabkan penyempitan saluran pernapasan (Aini et al., 2018).

Reactive Oxygen Spesies (ROS) yaitu suatu senyawa memiliki satu atau lebih elektron yang tidak berpasangan sehingga tidak stabil dan reaktif. Senyawa Oksigen Reaktif sangat berbahaya, yang akan merusak sel apabila tidak diredam, hal keadaan ini yag dikenal dengan stres oksidatif. Salah satu senyawa oksigen reaktif yang paling berbahaya adalah radikal hidroksil, yang akan memberikan dampak negatif terhadap membran sel. Radikal hidroksil dapat menimbulkan reaksi rantai yang dikenal dengan perokidasi lipid. Radikal bebas tersebut tidak menimbulkan efek negatif dalam tubuh bila terdapat dalam jumlah yang seimbang karena tubuh memiliki sistem antioksidan yang mampu menetralisirnya, tetapi apabila terjadi ketidakseimbangan antara radikal bebas dan antioksidan dalam tubuh, dimana jumlah radikal bebas lebih banyak dari pada antioksidan, maka akan timbul suatu keadaan yang disebut oksidatif stress. Keadaan oksidatif stres ini, bila dibiarkan dalam waktu yang lama, maka bisa saja menimbulkan keganasan, inflamasi, aterosklerosis, penuaan, iskemia, dan hemolisis (Elmatris et al., 2015).

Asap rokok elektronik dari hasil pemanasan megeluarkan uap berisi nikotin yang berasal dari cairan rokok elektronik. Rokok elektronik menggunakan cairan yang mengandung nikotin pada konsentrasi tertentu, namun baik rokok tembakau maupun rokok elektronik sama-sama berbahaya sebab keduanya tetap mengandung nikotin. Radikal bebas yang ditimbulkan oleh asap rokok tidak stabil dan 
mempunyai reaktivitas yang tinggi. Reaktivitasnya yang tinggi ini dapat merusak seluruh tipe makromolekul seluler termasuk karbohidrat, protein, lemak, dan asam nukleat (Tooy et al., 2016).

Rokok merupakan faktor resiko utama PPOM (penyakit paru obstruktif menahun) yang utama. Asap rokok dapat mengganggu aktivitas bulu getar saluran pernapasan, fungsi makrofag, dan mengakibatkan hipertrofi kelenjar mukosa. Resiko PPOM yang diakibatkan oleh rokok empat kali lebih besar daripada bukan perokok. Westenberger (2009) menyatakan bahwa kandungan rasa tambahan pada rokok elektrik juga mengandung bahan karsinogen yang berbahaya bagi manusia, termasuk nitrosamine, bahan-bahan kimia toksik seperti dietilen glikol, dan komponen bahan spesifik tembakau anabasine, myosamine, dan betanicotyrine.

\section{METODE}

\section{Pengambilan Darah}

Pengambilan darah dilakukan pada hari ke 31 penelitian. Darah diambil dari sinus orbitalis dengan hematokrit sebanyak $3 \mathrm{ml}$ dan ditampung dalam tabung eppendorf yang telah berisi EDTA. Sampel yang digunakan untuk pengukuran konsentrasi GPx dan Catalase adalah plasma darah. Darah yang terkumpul selanjutnya disentrifugasi dengan kecepatan $1000 \mathrm{rpm}$ selama 10 menit pada suhu $4{ }^{\circ} \mathrm{C}$. Plasma yang terbentuk dipindah ke dalam tabung baru dan disimpan pada suhu $-80^{\circ} \mathrm{C}$ sampai siap untuk dianalisis.

\section{Pengukuran kadar GPx}

Pengukuran kadarglutation peroksidase dilaksanakan di Laboratotium PAU Pangan dan Gizi Universitas Gadjah Mada. Alat yang digunakan yaitu spektofotometer pada panjang gelombang $340 \mathrm{~nm}$. Pengukuran kadar enzim glutathion perokidase (GPx) dilakukan dengan cara sebanyak $100 \mathrm{uL}$ plasma diencerkan dengan $200 \mathrm{uL} \mathrm{NaCl}$ fisiologis (larutan 0,85\% NaCl). Diambil 0,1 mL larutan tersebut dan ditambahkan 0,4 mL triton-X 0,5\%, dan seterusnya disebut hemolisat. Ke dalam tabung uji diambil 100 $\mathrm{uL}$ hemolisat dan ditambahkan $100 \mathrm{uL}$ larutan Drabkin lalu dikocok, kemudian ditambahkan 2,6 mL bufer fosfat dan dikocok perlahan. Berturut-turut ditambahkan 0,1 mL NADPH, 0,01 mL GSSG-R, 0,01 $\mathrm{mL}$ NaN3, 0,1 mL GSH, dan dikocok. Sebelum dibaca laju absorbansinya dengan spektrofotometer pada panjang gelombang $340 \mathrm{~nm}$, ke dalam kuvet silika yang berisi larutan yang akan dibaca absorbansinya ditambahkan $1 \mathrm{~mL} \mathrm{H} \mathrm{H}_{2} \mathrm{O}_{2}$. Pembacaan absorbansi dilakukan dengan selang waktu 1 sampai 2 menit. Untuk pembuatan blanko digunakan $100 \mathrm{uL}$ akuades sebagai pengganti hemolisat (Winarsi et al., 2012). Penghitungan glutation peroksidase mengunkan rumus sebagai berikut:

$(\mathrm{U} / \mathrm{mg})=8412 \times \Delta \mathrm{A} 340 \mathrm{~nm} / \mathrm{menit}$

\section{Pengukuran kadar Catalase}


Pengukuran kadar catalase dilaksanakan di Laboratotium PAU Pangan dan Gizi Universitas Gadjah Mada. Alat yang digunakan yaitu spektofotometer pada panjang gelombang $240 \mathrm{~nm}$. Pengukuran kadarcatalase plasma diawali dengan pembuatan lisat: $200 \mathrm{uL}$ plasma ditambahkan $800 \mathrm{uL}$ larutan 0,5\% triton X-100, kemudian dipersiapkan larutan standar untuk pengukuran sampel. Dibuat larutan induk dengan melarutkan $10 \mathrm{uL}$ katalase dalam $50 \mathrm{~mL}$ bufer fosfat. Larutan standar dibuat dengan melarutkan 0,5 mL larutan induk dalam 9,5 mL bufer fosfat (1/20) dan 0,5 mL larutan induk dalam 19,5 $\mathrm{mL}$ bufer fosfat (1/40). Sebanyak $10 \mathrm{uL}$ lisat dicampurkan dengan $12,5 \mathrm{~mL}$ bufer fosfat. Reaksi mulai terjadi setelah ditambahkan $1 \mathrm{~mL} \mathrm{H}_{2} \mathrm{O}_{2}$. Seluruh larutan divorteks perlahan, lalu penurunan absorbansi dibaca dengan spektrofotometer pada panjang gelombang $240 \mathrm{~nm}$ (Yuniastuti et al., 2015). Perhitungan catalase menggunakan rumus sebagai berikut:

$$
(\mathrm{nmol} / \mathrm{ml})=\frac{(\Delta \text { Absorbansi uji- } \Delta \text { Absorbansi Blanko }) / \text { menit }}{\left.\left(\text { Molaritas } \mathrm{H}_{2} \mathrm{O}_{2}\right) \times \text { (volume sampel yang diukur }\right)} \quad \mathrm{x} \text { faktor pengenceran }
$$

\section{Analisis Data}

Analisis data dilakukan secara statistik pada penelitian ini menggunakan statistik parametrik, jika data tidak terdistribusi normal dan homogen maka menggunakan statistik non parametrik Mann Whitney. Dalam penelitian ini mengunakan analisis data uji statistik one way Anova. Sebelum dilakukan uji tersebut, dilakukan uji normalitas data dan homogenitas terlebih dahulu. Uji normalitas menggunakan uji Kolmogorov-Smirnov test dilanjutkan uji homogenitas dengan uji Levene test (Wulandari, 2016). Kemudian untuk mengetahui perbedaan rata-rata antara kelompok dilakukan uji komparasi menggunakan uji One Way Anova dan dilanjutkan dengan uji Least Significant Differences (LSD). Analisis statistik dibantu dengan program SPSS (Statistical Product and Service Solutions) for windows versi 2.0.

\section{HASIL DAN PEMBAHASAN}

Penelitian ini dilakukan untuk menganalisis kadar GPx dan pada tikus yang dipapar rokok elektrik. Variabel yang diamati dalam penelitian ini adalah kadar GPx dan katalase pada darah. Paparan rokok elektrik dilakukan selama 30 hari dengan dosis kadar nikotin bervariasi $3 \mathrm{mg}, 6 \mathrm{mg}$ dan $9 \mathrm{mg}$.

Hasil penelitian dari pengukuran kadar GPx dan katalase setelah perlakuan mengalami perubahan. Hasil uji Kolmogorov-Smirnov pada kadar GPx menunjukkan bahwa data tersebut terdistribusi normal $(0,454>0,05)$ dan hasil uji Levene test memiliki varian data yang homogen $(0,702>0,05)$. Hasil uji Kolmogorov-Smirnov pada kadar katalase menunjukkan data tersebut berdistribusi normal $(0,454>0,05)$ dan uji Levene test memiliki varian data yang tidak homogen $(0,00<0.05)$. Hasil uji one way ANOVA menunjukkan kadar GPx memiliki signifikasi sebesar 0,00 atau lebih kecil dari derajat kemaknaan 0,05 ( $\mathrm{p}<0,05)$. Hasil uji non parametrik Kruskal Wallis menunjukkan kadar katalase memiliki signifikasi 0,00 atau lebih kecil dari derajat kemaknaan 0,05 $(p<0,05)$. Maka, 
artinya paparan rokok elektrik berpengaruh signifikasi terhadap kadar GPx dan katalase pada darah tikus.

Tabel 1. Hasil rearata kadar GPx dan katalase

\begin{tabular}{|l|l|l|l|}
\hline \multicolumn{1}{|c|}{ Kelompok } & \multicolumn{1}{|c|}{ Perlakuan } & \multicolumn{1}{c|}{$\begin{array}{c}\text { Kadar GPx } \\
\mathbf{( U / m g )}\end{array}$} & \multicolumn{1}{c|}{$\begin{array}{c}\text { Kadar katalase } \\
(\mathbf{n m o l} / \mathbf{m l})\end{array}$} \\
\hline K- & Normal & $78,33 \pm 1,90^{\mathrm{a}}$ & $6,59 \pm 27,50^{\mathrm{a}}$ \\
\hline K+ & Rokok kretek 3 batang & $19,80 \pm 2,42^{\mathrm{b}}$ & $1,86 \pm 3,50^{\mathrm{b}}$ \\
\hline KP1 & $\begin{array}{l}\text { Rokok elektrik kadar 3 } \\
\text { mg }\end{array}$ & $72,02 \pm 1,66^{\mathrm{c}}$ & $5,06 \pm 21,50^{\mathrm{c}}$ \\
\hline KP2 & $\begin{array}{l}\text { Rokok elektrik kadar 6 } \\
\text { mg }\end{array}$ & $58,52 \pm 2,82^{\mathrm{d}}$ & $3,93 \pm 15,50^{\mathrm{d}}$ \\
\hline KP3 & $\begin{array}{l}\text { Rokok elektrik kadar } 9 \\
\text { mg }\end{array}$ & $40,25 \pm 2,03^{\mathrm{e}}$ & $2,46 \pm 9,50^{\mathrm{e}}$ \\
\hline
\end{tabular}

Keterangan: angka yang diikuti oleh huruf pada kolom yang sama menunjukkan perbedaan pada setiap kelompok perlakuan dengan taraf ketelitian $\mathrm{p}<0,05$.

Hasil uji LSD dan Mann Whitney (Tabel 1) menunjukkan perbedaan antar kelompok perlakuan. Penelitian ini menunjukkan bahwa kelompok K- (kontrol negatif) memiliki kadar GPx sebesar 78,33 dan katalase 6,59. Kelompok kontrol negatif digunakan sebagai kelompok standar untuk mengetahui kadar GPx dan katalase pada darah tanpa diberi perlakuan paparan rokok elektrik. Jumlah kadar GPx dan katalase pada kelompok kontrol berbeda nyata dengan $\mathrm{K}+, \mathrm{KP} 1, \mathrm{KP} 2$, dan KP3.

Pada kelompok $\mathrm{K}+$ (kontrol positif) merupakan kelompok yang diberi perlakukan paparan dengan rokok kretek 3 batang memiliki kadar GPx dan katalase terendah yakni 19,80 dan 1,86. Kadar GPx dan katalase pada kelompok K+ berbeda nyata dengan semua kelompok lainnya (K-, KP1, KP2, dan KP3). Pada kelompok KP1 yaitu kelompok perlakuan paparan rokok elektrik kadar 3 mg dengan kadar GPx dan katalase yaitu 72,02 dan 5,06. Kadar GPx dan katalase pada kelompok ini berbeda nyata dengan kelompok lainnya (K-, KP1, KP2, dan KP3).

Pada kelompok KP2 merupakan kelompok perlakuan rokok elektrik kadar 6 mg dengan kadar GPx dan katalase yaitu 58,82 dan 3,93. Kadar GPx dan katalase pada kelompok ini berbeda nyata dengan kelompok lainnya (K-, K+, KP1, dan KP3). Pada kelompok KP3 merupakan kelompok perlakuan rokok elektrik kadar 9 mg dengan kadar GPx dan katalase yaitu 40,25 dan 2,46. Kadar GPx dan katalase pada kelompok ini berbeda nyata dengan kelompok lainnya (K-, K+, KP1, dan KP2).

Hasil penelitian menunjukkan pemaparan asap rokok elektrik menyebabkan penururnan kadar GPx dan katalase pada darah tikus. Glutation peroksidase adalah selonoprotein yang terdiri atas empat sub unit protein yang mengkatalis reaksi reduksi $\mathrm{H}_{2} \mathrm{O}_{2}$ menjadi senyawa organik hidroperoksida $(\mathrm{ROOH})$. Glutation banyak ditemukan dalam sitosol hati. Glutathione ( $\gamma$-glutamylcysteinylglycine, GSH) adalah antioksidan sulfhydryl (- SH), antotoksin dan kofaktor enzim. GSH ada dimana-mana termasuk hewan, tumbuhan, tanaman dan mikroorganisme, larut dalam air dan berada di dalam sitosol 
dari sel atau substrat larut dalam air lainnya. Dan karena jumlahnya yang cukup besar maka disebutkan sebagai antioksidan dalam sel yang mayor (Parwata, 2016).

Mekanisme kerja dari GSH didalam proses peredaman radikal bebas yaitu dalam segi kemampuananya mereduksi hidroksil radikal $(. \mathrm{OH})$ yang berasal dari reaksi Fenton.

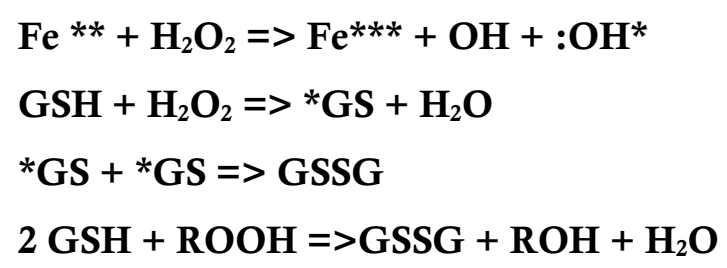

Disamping itu enzim Glutathion peroxidase menetralisir Hidrogen Peroksida $\left(\mathrm{H}_{2} \mathrm{O}_{2}\right)$ dengan cara mengambil hydrogen untuk membentuk $2 \mathrm{H}_{2} \mathrm{O}$ dan satu GSSG, sedangkan enzyme glutathione reduktase akan menjadikan GSSG, dengan menggunakan enzime NADPH sebagai sumber hidrogen, menjadi GSH kembali

\section{$2 \mathrm{GSH}+\mathrm{H}_{2} \mathrm{O}_{2}=>\mathrm{GSSG}+2 \mathrm{H}_{2} \mathrm{O}$}

Dengan kata lain glutathione di sini mencegah hidroksil radikal yang dapat merubah molekul lemak menjadi lemak radikal (.L) atau peroksida lemak (LOO.) melalui dua sisi yaitu mencegah terbentuknya hydroksil radikal ( .OH) bereaksi dengan molekul lemak atau mencegah terbentuknya hidroksil radikal dengan merubah Hidrogen Peroksida $\left(\mathrm{H}_{2} \mathrm{O}_{2}\right)$ menjadi molekul air.

Pada kelompok K- (kontrol negatif) memiliki kadar GPx tertinggi yang berbeda nyata dibandingkan dengan semua kelompok lainnya. Pada kelompok K+ (kontrol positif) memiliki kadar GPx lebih rendah dari kelompok K- (kontrol negatif) dan merupakan kelompok dengan kadar GPx dengan kadar terendah dibanding kelompok lainnya. Pemaparan rokok kretek pada tikus menurunkan kadar GPx secara bermakna dibandingkan kondisi normal. Gluthathion peroksidase (GPx) merupakan salah senyawa utama perlindungan endogen dari kerusakan oksidatif. Enzim ini mengkatalis reduksi hidrogen peroksida dan peroksida lemak (LOOH) oleh gluthathion. Gugus sulfhidril pada gluthathion (GSH) berfungsi sebagai donor elektron, dan dioksidasi menjadi bentuk disulfida (GSSG), yang akan direduksi kembali oleh gluthathion reduktase menjadi bentuk sulfhidril. Gluthathion peroksidase merupakan salah senyawa utama pertahanan sel endogen apabila antioksidan lain tidak ada. Gluthathion peroksidase merupakan antioksidan enzimatik, salah satunya membutuhkan Selenium (Se) untuk aktifitasnya, sehingga kadar GPx dapat menggambarkan kadar Se juga. Semakin rendah kadar GPx, semakin rendah pula kadar Se dalam darah (Sulistyowati, 2010). Hal ini dikarenakan efek dari asap rokok yang mengandung radikal bebas yang kuat dan dapat menyebabkan stress oksidatif. Stress oksidatif dapat menyebabkan gangguan pada proses oksidasi sehingga terjadi peningkatan produksi radikal bebas. Peningkatan radikal bebas ini disebabkan karena antioksidan yang tersedia didalam tubuh tidak mampu lagi mengubah oksigen reaktif $\left(\mathrm{O}^{*}\right)$ menjadi senyawa yang netral $\left(\mathrm{O}_{2}\right)$. Antioksidan tersebut memberikan pertahanan yang sangat efektif, tetapi stress oksidatif yang berat dapat berakibat pada habisnya antioksidan yang tersedia (Kurnia \& Rauf, 2011).

Pada kelompok perlakuan KP1, KP2, dan KP3 yang diberikan perlakuan paparan rokok elektrik mengalami penurunan kadar GPx dan berbeda nyata dengan kelompok K- (kontrol negatif), kelompok 
KP3 yang memiliki kadar GPx terendah. Ketika tikus diberi perlakuan paparan rokok elektrik maka terjadi peningkatan peroksida lipid. Dalam aktivitas enzim yang normal, peningkatan konsentrasi subtrat, yaitu molekul hidrogen peroksida $\left(\mathrm{H}_{2} \mathrm{O}_{2}\right)$ dapat meningkatkan aktivitas enzim. Namun pada saat sisi aktif semua enzim berikatan dengan substrat, penambahan substrat tidak dapat meningkatkan kecepatan reaksi enzim selanjutnya, sehingga terjadi penurunan aktivitas enzim GSH peroksidase (GPx). Selain itu, produk radikal bebas dapat merusak senyawa protein karena senyawa oksidan tersebut dapat mengadakan interaksi dengan asam-asam amino penyusun protein. Bagian yang mudah diserang radikal bebas adalah gugus sulfidril (SH). Serangan radikal bebas pada gugus tersebut akan membentuk ikatan disulfida (-S-S-) dan menimbulkan ikatan intra dan antar molekul sehingga protein kehilangan fungsi biologis. Misalnya protein yang berperan sebagai enzim akan kehilangan aktivitasnya (Winarsi, 2007). Oleh sebab itu, aktivitas enzim GSH peroksidase (GPx) yang merupakan molekul protein kompleks dapat mengalami penurunan dengan adanya pemberian perlakuan paparan rokok elektrik (Ifanyanti, 2017).

Berdasarkan hasil penelitian diatas menunjukkan bahwa kadar GPx pada kelompok K+ lebih kecil daripada kelompok perlakukan KP1, KP2 dan KP3. Hal ini dikarenakan rokok elektrik terlihat dan berfungsi seperti rokok konvensional biasa, akan tetapi tidak membakar sejumlah tembakau. Rokok elektrik secara umum memiliki baterai dan perangkat elektronik yang memproduksi asap atau semacam kabut. Kandungannya selalu berisi nikotin tetapi ada juga yang tidak memiliki kandungan nikotin sama sekali dan berisi propilen keseluruhan sebagai produk pengurangan dampak buruk tembakau. Dari berbagai penelitian yang dilakukan menyimpulkan bahwa asap rokok elektrik tidak meninggalkan racun pembakaran seperti pada rokok tembakau. Hanya meninggalkan jejak nikotin saja (Lorensia et al., 2017). Ada beberapa studi yang telah menguji efek akut bekas paparan uap rokok elektrik. Seperti yang di teliti oleh menemukan bahwa perokok pasif rokok elektrik tidak mempengaruhi darah pada subyek manusia.

Kecanduan atau keinginan untuk terus merokok disebabkan kandungan nikotin dalam rokok yang memberikan efek adiktif. Efek nikotin dapat menimbulkan kecanduan dikarenakan adanya interaksi antara nikotin dengan reseptor kolinergik nikotin di otak yaitu Nicotinic Acetylcholine Receptors (nAChRs) di daerah mesolimbik dopamin system di Ventral Tegmental Area (VTA) neuron yang mengawali aktivasi Central Nervus System (CNS) termasuk system Mesoaccumbens Dopamin. Reseptor nikotinin mengatur pelepasan dopamin. Nikotin mengubah aktivitas VTA untuk meningkatkan sekresi dopamine. Dopamin yang dilepaskan berperan dalam pengontrolan fungsi aktivitas lokomotorik kognisi, emosi, reinsformenpositif, serta regulasi endokrin. Akibat dari pelepasan dopamine, maka akan timbul perasaan nyaman bagi perokok (Lorensia et al.,2017).

Enzim katalase merupakan salah satu dari komponen sistem pertahanan antioksidan tubuh berupa enzim yang berfungsi untuk mencegah pembentukan radikal hidroksil dan melindungi sel dari keadaan stres oksidatif. Enzim katalase bekerja dengan cara menguraikan hidrogen peroksida $\left(\mathrm{H}_{2} \mathrm{O}_{2}\right)$ dan melindungi tubuh dari radikal hidroksil yang reaktif. Maka dari itu, jika terjadi penurunan aktivitas enzim katalase dapat mengakibatkan efek yang merugikan karena terjadi akumulasi dari radikal bebas 
(Setiawan \& Nugroho, 2018). Enzim katalase akan mengkatalis dekomposisi salah satu ROS yakni hidrogen peroksida menjadi air dan oksigen sehingga dapat melindungi sel dari kerusakan oksidatif.

Pada kelompok K- (kontrol negatif) memiliki kadar katalase tertinggi yang berbeda nyata dibandingkan dengan semua kelompok lainnya. Pada kelompok K+ (kontrol positif) memiliki kadar katalase lebih rendah dari kelompok K- (kontrol negatif) dan merupakan kelompok dengan kadar katalase dengan kadar terendah dibanding kelompok lainnya. Pemaparan rokok kretek yang diberikan pada kelompok $\mathrm{K}+$ (kontrol positif) mengakibatakan kadar enzim katalase mengalami penurunan dalam darah. Hal ini dikarenakan rokok kretek yang memiliki kandungan zat berbahayas seperti nikotin, tar, kadmium, dll dapat menyebabkan kerusakan sel hati dan menghambat/menurunkan biosintesis katalase di hati. Kadar enzim katalase di darah pada kelompok K- (kontrol negatif) memiliki kadar yang normal ini disebabakan tidak adanya kandungan zat berbahaya berupa radikal bebas yang masuk dalam darah, yang mana katalase di dalam hati akan tetap melakukan biosintesis secara efektif. Sedangkan, pada kelompok yang dipapar rokok kretek mengalami penurunan kadar enzim katalase. Hal ini karena terjadi kerusakan sel dan terjadi penghambatan biosinstesis katalase di hati secara bermakna yang mengakibatkan katalase bedifusi ke dalam darah. Sehingga, jumlah katalase di darah menurun setelah diberi paparan rokok kretek (Asterina, 2012).

Pada kelompok perlakuan KP1, KP2, dan KP3 yang diberikan perlakuan paparan rokok elektrik mengalami penurunan kadar katalase dan berbeda nyata dengan kelompok K- (kontrol negatif), kelompok KP3 yang memiliki kadar katalase terendah. Hal ini dapat terjadi karena dalam keadaan stres, aktivitas katalase berkurang karena komponen enzim katalase yang merupakan kompleks protein sudah dirusak oleh radikal bebas, karena target radikal bebas adalah merusak komponen senyawa protein, lipid dan karbohidrat. Radikal bebas menyerang pada gugus thiol yang terdapat pada komponen protein (Winarsi, 2007). Selain itu stres oksidatif dapat menyebabkan cedera jaringan dimana terjadi kerusakan pada semua target molekul, DNA, protein dan lipid (lipid peroksidasi) (Halliwel, 2001). Selain itu radikal bebas dapat menyebabkan inaktivasi enzim, dan kerusakan membran (Khairunanda et al., 2014). Maka dari itu diperlukan antioksidan eksogen untuk membantu kerja dari antioksidan endogen. Seperti yang diketahui bahwa selain enzim katalase, terdapat enzim antioksidan endogen lain juga seperti superoksida dismutase dan glutation. Kerja dari enzim katalase sama halnya seperti enzim glutation yaitu mengubah hidrogen peroksida menjadi air dengan reaksi sebagai berikut (Apriana et al., 2016):

\section{$2 \mathrm{GSH}+\mathrm{H}_{2} \mathrm{O}_{2}=>\mathrm{GSSG}+2 \mathrm{H}_{2} \mathrm{O}$}

pada saat peningkatan aktivitas radikal bebas, maka tubuh melakukan mekanisme homeostatis dengan memproduksi antioksidan endogen untuk mencegah terjadinya stres oksidatif, namun tubuh terkadang juga memerlukan bantuan dari asupan senyawa antioksidan eksogen (berasal dari makanan yang dikonsumsi) dalam jumlah yang lebih banyak untuk mengeliminir dan menetralisir efek radikal bebas (Astuti, 2008; Sies \& Stahl, 2001).

Keberadaan zat toksik seperti nikotin pada rokok ini disamping menghasilkan suatu radikal bebas, juga akan dapat menurunkan ketersediaan zat antioksidan tubuh, dan juga dapat mempengaruhi aktifitas enzim, menghambat absorbsi mineral runutan, mengikat protein, serta merubah homeostasis 
kalsium. Mekanisme zat toksik seperti nikotin pada rokok meracuni tubuh menyebabkan terjadinya kerusakan oksidatif. Toksik yang ditimbulkan akibat adanya nikotin ini akan mengahasilkan suatu radikal bebas, yang mana radikal bebas dapat menghasilkan suatu senyawa oksigen reaktif (SOR) yaitu suatu senyawa memiliki satu atau lebih elektron yang tidak berpasangan sehingga tidak stabil dan reaktif. Senyawa Oksigen Reaktif sangat berbahaya, yang akan merusak sel apabila tak diredam, hal keadaan ini yang dikenal dengan stress oksidatif. Peningkatan radikal bebas pada tikus yang terpapar rokok menyebabkan menurunnya aktifitas katalase, karena $\mathrm{H}_{2} \mathrm{O}_{2}$ akan terurai menjadi $\mathrm{OH}$ ( Radikal Hidroksil) yang sangat toksik, dapat merusak lemak, protein dan DNA (Elmatris et al., 2015).

\section{SIMPULAN}

Paparan rokok elektrik berpengaruh terhadap kadar GPx di tandai dengan adanya penurunan kadar GPx. Paparan rokok elektrik berpengaruh terhdap kadar katalase di tandai dengan adanya penurunan kadar katalase.

\section{UCAPAN TERIMA KASIH}

Saya ucapkan terima kasih kepada semua pihak yang sudah membantu dalam kelancaran penelitian ini.

\section{DAFTAR PUSTAKA}

Aini, A. N., Harjana, M. P. \&Tri. (2018). Pengaruh Paparan Asap Rokok Elektrik (Vapour) dengan Berbagai Variasi Dosis Terhadap Gambaran Histologi Bronkiolus Mencit (Mus Musculus). Jurnal Prodi Biologi, 7(8).

Apreliantino, N. P. (2012). Pengaruh Sidestream Smoke pada Kadar SGPT Tikus wistar Jantan (Rattus norvegicus). UNEJ Jurnal, 1, 1-4.

Apriana, R., Supriyatin, \& Rahayu, S. (2016). Pengaruh Aktivitas Fisik Maksimal dan Ekstrak Daun Bambu Manggong (Gigantochloa manggong) terhadap Aktivitas Katalase pada Hati Tikus Putih (Rattus Norvegicus). Bioma, 12(1).

Asterina, E. (2012). Pengaruh Timbal Asetat terhadap Aktivitas Enzim Katalase Hati Tikus Putih Jantan. Majalah Kedokteran Andalas, 2(3).

Astuti, S. (2008). Isoflavon Kedelai dan Potensinya sebagai Penangkap Radikal Bebas. Staf Pengajar Jurusan Teknologi Industri Pertanian Fakultas Pertanian Universitas Lampung.

Chevion, S., Moran, D. S. \& Heled, Y. (2003). Plasma Antioxidant Status and Cell Injury After Severe physical Exercise. Proc Nati Acad Sci, 100(9), 5119-5123

Christensen, L. V., Holm, M. A. \& Kongerud, J. (2016). Occurrence, Charasteristic, and Predictiors of Pain in Patiens with Chronic Obstructive Pulmonary Diases. Pain Managtemen Nursing, 1(1), 112.

Elmatris, S., Kadri, H. \& Yerizel, E. (2015). Efek Pemberian Vitamin C Terhadap Aktifitas Katalase Hati Tikus Galur Wistar yang Terpapar Ion Pb. Jurnal Kesehatan Andalas, 4(1).

Gutowski, M. \& Kowalczyk, S. (2013). A Study of Free Radical Chemistry: Their Role and Pathophysiological Significance. Acta Biochim Pol, 60(1), 1-16.

Hasna, N. A. E., Chayo, K. \& Widagdo, L. (2017). Faktor-Faktor yang Berhubungan dengan Penggunaan Rokok Elektrik Pada Perokok Pemuladi SMA Kota Bekasi. Jurnal Kesehtan Masyarakat, 5(3).

Ifanyanti, T. (2017). Pengaruh Vitamin E terhadap Aktivitas Enzim Glutation Peroksidase (GSH-Px) pada Tikus Strain Witar jantan yang Terpapar Karbon Tetraklorida $\left(\mathrm{CCl}_{4}\right)$. Jurnal Ilmu Kesehatan, $1(1)$.

Lorensia, A., Yudiarso, A. \& Herwansyah, F. R. (2017). Persepsi, Efektifitas dan Keamanan Penggunaan Rokok Elektrik (E-Cigarette) Oleh Perokok Aktif sebagai Terapi dalam Smoking 
Cessation: Mixed Methods dengan Pendekatan Studi Kuantitatif dan Kualitatif. Journal of Tropical Pharmacy and Chemistry, 4(2).

Khairunanda, Nuryadi, Suhartono, E. \& Triawanti. (2014). Efek Pajanan Kadmium (Cd) Terhadap Aktivitas Katalase Darah Tikus Putih (Rattus Norvegicus). Berkala Kedokteran, 10(1), 25-30.

Kurnia, P. \& Rauf, R. (2011). Optimasi Ekstraksi terhadap Kadar Fenolik dan Aktivitas Penangkapan Radikal DPPH Ekstrak Gambir (Uncaria gambir). Seminar Nasional Membangun Daya Saing Produk PAngan Berbasis Bahan Baku Lokal. Surakarta:17-24.

Parwata, A. I. M. O. 2016. Antioksidan. Bali: Universitas Udayana.

Raherison, C. \& Girodet, P. O. (2009). Epidemiology of COPD. Europe Respiratory Review, 18(114), 213221.

Rohmani, A., Yazid, N. \& Rahmawati, A. A. (2018). Rokok Elektrik dan Rokok Konvensional Merusak Alveolus Paru. Seminar Nasional Unimus. Semarang:1.

Setiawan, J. \& Nugroho, T. (2018). Pengaruh Ekstrak Kulit Manggis terhadap Enzim Katalase Hepar Tikus Terpapar Minyak Jelantah. Diponegoro Medical Journal, 7(1), 263-272.

Sies, H. \& Stahl, W. (2001). Vitamins E And C, Betacarotene, and Other Carotenoids as Antioxidants. American Journal of Clininical \& Nutrition, (62),1315S-21S.

Sulistyowati, Y. (2010). Pengaruh Pemberian Likopen terhadap Status Antioksidan (Vitamin C, Vitamin E dan Gluthathion Peroksidase) Tikus (Rattus Norvegicus Galur Sprague Dawley) Hiperkolesterolemik. E- Journal Undip, 1(1).

Tooy, M., Tendean, L. \& Satiawati, L. (2016). Perbandingan kualitas spermatozoa tikus wistar (Rattus norvegicus) yang diberi paparan asap rokok dengan asap rokok elektronik. Jurnal e-Biomedik, 4(2).

Westenberger, B. J. (2009). Evaluation of e-Cigarettes. St. Louis, MO: Departement of Health and Human Service, Fod and Drug Administration, Center for Drug Evaluation and Research, Division of Pharmaceutical Analysis.

WHO. (2013). Enforcing bans on tabacco advertising promotion and sponsorship.

Winarsi, H. (2007). Antioksidan Alami \& Radikal Bebas. Yogyakarta: Kanisius.

Winarsi, H., Wijayanti, Siwi P. M. \& Purwanto, A. (2012). Aktivitas Enzim Superoksida Dismutase, Katalase, dan Glutation Peroksidase Wanita Penderita Sindrom Metabolik. MKB, 44(1).

Wulandari, E. 2016. Efek Ekstrak Kulit Rambutan terhadap Kadar MDA dan SOD Tikus yang Dipapar Asap Rokok. Skripsi, Universitas Negeri Semarang.

Yuniastuti, A., Kamilatussainah, \& Sasi, F. A. (2015). Pengaruh Pemberian Madu Kelengkeng Terhadap Aktivitas Enzim Superoxide Dismutase Dan Katalase Pada Tikus Yang Diinduksi Pb Asetat. Prosiding SNST ke-6 Tahun 2015 Fakultas Teknik Universitas Wahid Hasyim Semarang. Semarang:100-103. 